\title{
Research on Systems Engineering of Recycling EV Battery
}

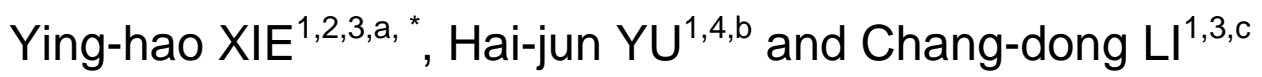 \\ ${ }^{1}$ Guangdong Brunp Recycling Technology Co., Ltd., Foshan 528244, China \\ ${ }^{2}$ Hunan Brunp End-of-Life Vehicles Recycling Co., Ltd, Changsha 410600, China \\ ${ }^{3}$ Guangdong Traction Battery \& Electric Vehicle Recycling Research Academician Workstation, \\ Foshan 528244, China \\ ${ }^{4}$ Graduate School of Central South University, Changsha 410083, China \\ aemail:diangong306@126.com, bemail:paper@brunp.com.cn, cemail:standard@brunp.com.cn, \\ *corresponding author
}

\section{Keywords: Electric Car, EV Battery, Recycle, Systems Engineering}

\begin{abstract}
Since the flash point of the electrolyte's organic solvent is very low, the use of improper dismantling way can easily cause the battery to ignite or even explode. Additionally, the residual voltage of the discard EV battery is very high, far exceeding human safety voltage. Improper dismantling way is easily short-circuit and caused the fire even personnel electric shock casualties. By analyzing the characteristics of hazardous characteristics and recycling technology of the EV battery, compared to professional EV battery recycling companies, waste electrical and electronic products recycling enterprises, traders, hazardous waste disposal sites, and even municipal solid waste recycling enterprise in recycling EV battery advantages and disadvantages. It shows that professional EV battery recycling companies have recycling and disposal qualification. The professional EV battery recycling companies can simultaneously physical and chemical recycling, and have a professional team and experience in dealing with all types of battery. Moreover, it can be better for the information confidential. EV battery recycling is a systematic and professional engineering, and should have a qualified professional battery recycling enterprises for recycling.
\end{abstract}

\section{Introduction}

According to Ministry of Public Security statistics, China's new energy vehicle population reached 583,200 , compared with 2014 growth of 169.48 percent by 2015. New energy automobile industry has been rapid development in the context of a series of policies favorable measures such as separate a lottery, cash subsidies, free of vehicle purchase tax, free vehicle and vessel tax, no restricting the number of driving, parking fee, etc.

In currently available lithium-ion battery materials and battery level of the manufacturing process, in the next 3 to 5 years [1] will usher in the first battery retired explosive growth. From the point of view of policy requirements, safety and environmental protection, recycling economy, green life cycle, when the EV battery reaches the end of life, to ensure that each waste battery recycling has become inevitable. The dangerous EV battery recycling is a professional, systematic project, including physical dismantling of the material and effective chemical recycling. The whole process requires specialized technologies, processes, space, equipment and personnel. EV Battery recycling industry outlook is promising. There are many edge industry would like to get involved in battery recycling, such as waste electrical and electronic products recycling enterprises, traders, hazardous waste disposal sites, and even municipal solid waste enterprises.

By analyzing the characteristics of hazardous characteristics and recycling technology of the EV battery, compared to professional EV battery recycling companies, waste electrical and electronic products recycling enterprises, traders, hazardous waste disposal sites, and even municipal solid waste recycling enterprise in recycling EV battery advantages and disadvantages, to guide the vehicle enterprises and EV battery production enterprises choose reasonable recycling processing enterprises. 


\section{EV Battery Recycling Technology}

Security risk. EV Battery powered by the pack modules, cell and battery management system. Is not easy to secure dismantling EV battery for internal structure of EV battery is complex, there are many different kinds of parts. Specification of dismantling is an important part of production safety. EV battery is different from small battery, EV battery with higher voltage and larger capacity. The Improper dismantling method prone to mutual contact between the battery and cause the battery to short circuit, and then causing the battery fire or explosion. EV Battery electrolyte is organic solution with lithium hexafluorophosphate. It will leads to the EV battery case broken, and electrolyte leakage volatility to the air, if use improperly way of dismantling. And it is easy to cause the battery ignition and combustion and even explosion, if the low flash point of the organic solvent exposure to oxygen in the air. In addition, lithium hexafluorophosphate exposed to air, decomposition in case of meet moisture in the air, produce toxic gases HF [2]. It is a serious threat to the dismantling personnel safety and potential significant risk of environmental pollution.

Therefore, dismantling technology reasonable, rational choice dismantling tools and equipment, the establishment of job training system, in strict accordance with dismantling procedures and develop effective contingency plans, it is five essential elements of safe dismantling EV battery. The flash point, melting point, boiling point of conventional lithium-ion EV battery electrolyte of organic solvent listed in Table 1.

Table 1 Physical Characteristics of EV battery electrolyte of organic solvent

\begin{tabular}{lcccccc}
\hline Solvent & EC & DEC & DMC & EMC & PC & DME \\
\hline Flash point $/{ }^{\circ} \mathrm{C}$ & 160 & 31 & 18 & 25 & 132 & 1 \\
Melting point $/{ }^{\circ} \mathrm{C}$ & 36.4 & -74.3 & 4.6 & -53 & -48.8 & -69 \\
Boiling point $/{ }^{\circ} \mathrm{C}$ & 248 & 126 & 91 & 110 & 242 & 83 \\
\hline
\end{tabular}

Recovery Technology. Battery pack system consists of modules, battery management systems, metal cabinet, cooling system, high and low voltage wiring harness, and some auxiliary components. Figure 1 is a typical EV battery dismantling process. The main direction through the physical recycling process, including the battery pack disassembled into battery module, the battery module disassembled into cells, the cells isolated dismantling. Electrode material of nickel, cobalt and manganese lithium (commonly known as the ternary material) was synthesis by pyrolysis, crushing, sorting obtain an electrode material powder, and finally through a series of impurity purification process, co-precipitation, sintered [3]. The ternary material is returned to the battery factory to re-prepare a battery. The directional recycling technology enables objects returned to native areas in the highest form. Thus providing a steady flow of resources and material for the remanufacturing native industry, not only created economic value, but also reduce strategic waste of resources. The directional recycling technology was first proposed and successfully engineering applied by Brunp. Moreover, it creates huge social, environmental and economic benefits.

EV Battery recycling is not only physically dismantling recycling or chemical recycling materials. However, EV battery recycling is a systematic project. If forcibly separate into two, that is, first EV battery was pay to the physical dismantling factory for dismantling, and then the disassembled battery product is supplied chemical recycling companies for recycling. Multiple transport process potentially not only increases the cost of recycling, but also increases the risk of environmental pollution. EV Battery recycling enterprises should also have the physical and chemical recovery capability. 


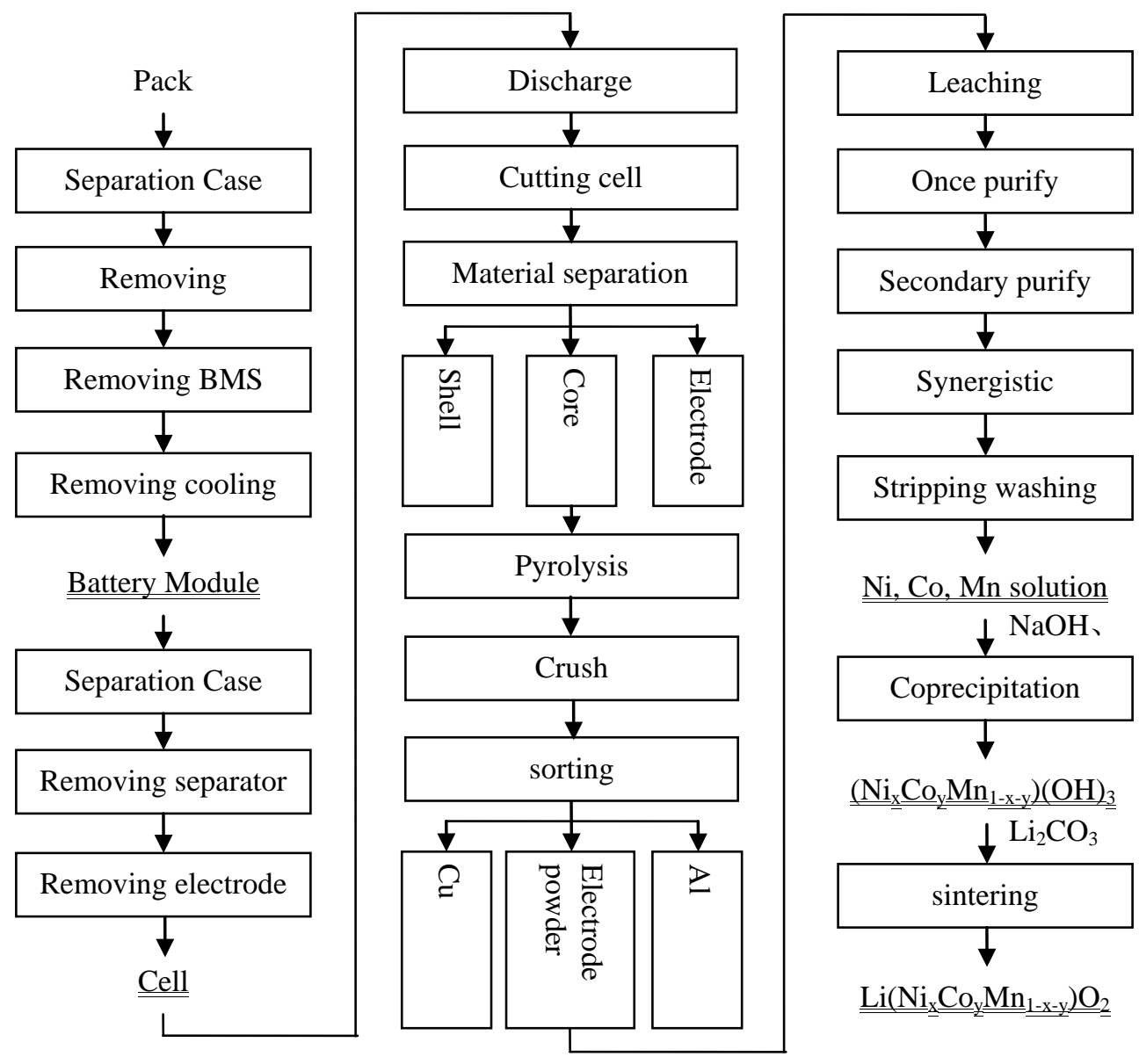

Figure 1 Typical physical and chemical recycling process of EV battery

Tools and Equipment. EV Battery nominal voltage is typically $385 \mathrm{~V}$, ternary materials lithium-ion battery nominal voltage of $3.7 \mathrm{~V}$, discharge cut-off voltage of $3.0 \mathrm{~V}$, even if discharge to $\mathrm{SOC}=0$, voltage is still up to $312 \mathrm{~V}$, while voltage is much more than the body safe voltage $36 \mathrm{~V}$ when discarded.

Recycling should be equipped with high-voltage battery insulated gloves, cut resistant gloves, helmets, anti-smashing insulated shoes, goggles, insulated rescue hook and other security equipment. Professional shields, special lifting tools, lifting equipment, dismantling tooling table, insulated suits and other tools to ensure that the process of dismantling is environmental friendliness and safety.

Safety Requirements. Battery dismantling should be used safety equipment strictly in order to ensure the safety of the dismantling process, such as cutting should be worn cutting gloves, goggles and the like. Dismantling process should have no less than two electrical permit holders who prohibited a person alone operation, should one person operation one person protection. The protection person should immediately use insulated rescue hook to implement the rescue, when happen to get an electric shock.

In lifting the EV battery before dismantling, rigging, lifting equipment bear the load should not exceed the rated lifting capacity. Spreader, lifting equipment should be promptly cut off switch, make the necessary insulation measures before maintenance. Battery pack shall be fixed at least three points, in order to ensure the stability of the lifting process. The external wires and appendages should be removed off before lifting to prevent lifting of the fall. Test should be carried out before the formal lifting crane. Crane test check all rigging, lifting equipment the forces, if found the problem the battery should be back into the ground. Try again after troubleshooting hanging, make sure everything is normal, before the official lifting.

Environmental Requirements. The collected waste liquor, such as hazardous waste, hazardous waste management practices and should be executive GB 18597. The resultant dismantling parts, materials, waste classification should be stored in appropriate containers and clearly identified. 
Components containing harmful substances (such as circuit boards, coolants, adhesives, etc.), shall identify the type of hazardous substances, and in accordance with the characteristics of hazardous waste classification, collection and storage reference HJ 2025. Container and apparatus should be able to prevent leakage, anti-spill, and routine inspection [4].

\section{EV Battery Recycling Situation}

China has already released relevant policy guidance. April 18, 2012, the State Council discussed and adopted the "Energy-saving and new energy automotive industry plan (2012-2020)" (the "Plan"), The "plan" that strengthen the EV battery cascade utilization and recycling management, and strict set battery recycling business access conditions. The "plan" clears management requirements and technical standards of EV battery collection, storage, transport, treatment, regeneration, final disposal and other aspects. The "Plan" clearly put forward access conditions of EV battery recycling companies. Under the premise of having a qualified recycling, the recycling enterprises should comply with the relevant technical standards and management requirements.

Currently, under the great support of electric vehicles national policies, the explosive growth of new energy vehicles has quietly come. Electric car as a new clean energy vehicles, will gradually replace traditional fuel vehicles become mainstream in the future market. EV Battery life is generally 3 to 5 years, with the termination of battery life, the number of retirement batteries will rapidly increase after 3 to 5 years. EV Battery recycling industry outlook is promising. There are many edge industry would like to get involved in battery recycling, such as waste electrical and electronic products recycling enterprises, traders, hazardous waste disposal sites, and even municipal solid waste enterprises [5]. EV Battery Recycling is a systematic and professional engineering, and should have a qualified professional battery recycling enterprises for recycling. Table 2 for these types of recycling companies advantages and disadvantages.

Table 2 Advantages and disadvantages of five types of recycling companies

\begin{tabular}{|c|c|c|}
\hline Type of Recycling company & Advantages & Disadvantages \\
\hline $\begin{array}{l}\text { Professional EV battery } \\
\text { recycling company }\end{array}$ & $\begin{array}{l}\text { have recycling and disposal } \\
\text { qualification. Can simultaneously } \\
\text { physical and chemical recycling, have } \\
\text { a professional team and experience in } \\
\text { dealing with all types of battery. }\end{array}$ & $\begin{array}{l}\text { Due to the high degree of specialization, } \\
\text { cost recovery by restricting the amount } \\
\text { of recovery, when less capacity to deal } \\
\text { with the higher costs. }\end{array}$ \\
\hline $\begin{array}{l}\text { Waste electrical and } \\
\text { electronic products recycling } \\
\text { business }\end{array}$ & $\begin{array}{l}\text { have recycling and disposal } \\
\text { qualification }\end{array}$ & $\begin{array}{l}\text { Can only physical recovery, do not have } \\
\text { the experience and professional team, no } \\
\text { ready-made equipment, processes and } \\
\text { technology in battery recycling strategic } \\
\text { resources. Cell fate cannot be } \\
\text { guaranteed. }\end{array}$ \\
\hline Merchant & pay high recycling prices & $\begin{array}{l}\text { Only have recycling qualification, no } \\
\text { disposal qualification and capability. } \\
\text { Cell fate cannot be guaranteed. Battery } \\
\text { technology cannot secret, it can easily } \\
\text { cause leaks. }\end{array}$ \\
\hline $\begin{array}{l}\text { Hazardous waste disposal } \\
\text { sites }\end{array}$ & $\begin{array}{l}\text { have recycling and disposal } \\
\text { qualification }\end{array}$ & $\begin{array}{l}\text { Can only physical recovery, do not have } \\
\text { the experience and professional team, no } \\
\text { ready-made equipment, processes and } \\
\text { technology in battery recycling strategic } \\
\text { resources. }\end{array}$ \\
\hline Garbage disposal business & $\begin{array}{l}\text { Most landfills manner, lower } \\
\text { processing costs }\end{array}$ & $\begin{array}{l}\text { Most do not have the qualification } \\
\text { process, wasting a lot of strategic } \\
\text { resources. Easy to cause environmental } \\
\text { pollution. }\end{array}$ \\
\hline
\end{tabular}




\section{Summary}

Since the flash point of the electrolyte's organic solvent is very low, the use of improper dismantling way can easily cause the battery to ignite or even explode. Additionally, the residual voltage of the discard EV battery is very high, far exceeding human safety voltage. Improper dismantling way is easily short-circuit and caused the fire even personnel electric shock casualties. "Energy-saving and new energy automotive industry plan (2012-2020)" clearly put forward access conditions of EV battery recycling companies. Under the premise of having a qualified recycling, the recycling enterprises should comply with the relevant technical standards and management requirements. EV Battery recycling is not only physically dismantling recycling or chemical recycling materials. However, EV battery recycling is a systematic and professional engineering, and should have a qualified professional battery recycling enterprises for recycling.

\section{Acknowledgement}

This research was financially supported by the national Torch Program projects (No. 2013GH061426), National Key Technology R\&D Program alternative project (subproject) (No. 2014BAC03B01) and strategic emerging industries core technology research projects in Guangdong Province (No. 2011A032302001).

\section{References}

[1] H.J. Yu, Y.H. Xie, Y.N Ou and C. D. Li, Research on storage security of waste battery for electric vehicle. Chinese Journal of Power Sources, 39 (2015) 745-748.

[2] H.J. Yu, Y.H. Xie and T.Z Zhang, Technical progress on power batteries recovery for electric vehicle, The Chinese Journal of Nonferrous Metals, 24 (2014) 448-460.

[3] Y.H. Xie, H.J. Yu, Y.N Ou and C. D. Li, Environmental impact assessment of recycling waste traction battery. Inorganic Chemicals Industry, 47 (2015) 43-46.

[4] H.J. Yu, Y.H. Xie, Y.N Ou and C. D. Li, Electric vehicle identity recognition based on traction battery coding, Chinese Journal of Power Sources, 40 (2016) 113-116.

[5] Y.H. Xie, H.J. Yu, Y.N Ou and C. D. Li, Research on business model for recycling traction battery, Advances in Engineering Research: Atlantis Press, (2015) 176-180. 